\title{
Prepartum anionic diet induces hyperchloremic acidosis in high-producing dairy cows without preventing subclinical hypocalcemia ${ }^{1}$
}

\author{
Keli D.C.L. Ramella ${ }^{2}$ (D), Luis G. Cucunubo Santos ${ }^{2}$, Thais H.C. Patelli ${ }^{3}$, \\ Karina K.M.C. Flaiban ${ }^{4}$ and Júlio A.N. Lisbôa ${ }^{5 *} \mathbb{C}$
}

\begin{abstract}
Ramella K.D.C.L, Cucunubo Santos L.G., Patelli T.H.C., Flaiban K.K.M.C. \& Lisbôa J.A.N. 2020. Prepartum anionic diet induces hyperchloremic acidosis in highproducing dairy cows without preventing subclinical hypocalcemia. Pesquisa Veterinária Brasileira 40(11):875-881. Departamento de Clínicas Veterinárias, Centro de Ciências Agrárias, Universidade Estadual de Londrina, Campus Universitário, Cx. Postal 10011, Londrina, PR 86057-970, Brazil.E-mail: janlisboa@uel.br

In this study we evaluated the effects of the prepartum anionic diet on the electrolyte balance and calcemia of high producing dairy cows in the first days of lactation, and investigated the impact on the frequency of subclinical hypocalcemia (SCH). Sixty healthy Holstein cows, producing $30 \mathrm{~kg}$ of milk/day, handled in intensive system (compost barn), were distributed in groups $(\mathrm{n}=15)$ according to lactation order: first, second, third, and fourth to sixth. In the last three weeks before calving they received a diet with negative DCAD $(-6 \mathrm{mEq} / 100 \mathrm{~g} \mathrm{DM})$ and high chloride content. After calving, they received a diet with positive DCAD (18mEq/100g DM). Urine $\mathrm{pH}$ was measured before calving. Serum $\mathrm{Na}^{+}, \mathrm{Cl}^{-}$, $\mathrm{K}^{+}$, and total Ca concentrations, and the strong ion difference $\left(\mathrm{SID}_{3}\right)$ were determined in samples taken soon after calving (0h), 24, 48, 72 and 96h after. The frequencies of SCH were determined considering the critical value of $2.125 \mathrm{mmol} / \mathrm{L}(8.5 \mathrm{mg} / \mathrm{dL})$. Two-way repeated measures ANOVA and chi-square test were used for comparisons. The cows eliminated acidic urine before calving. $\mathrm{Na}^{+}, \mathrm{K}^{+}, \mathrm{Cl}$, and $\mathrm{SID}_{3}$ values did not differ between groups. $\mathrm{Na}^{+}$and $\mathrm{K}^{+}$did not vary between days; $\mathrm{Cl}^{-}$was elevated at calving and decreased until $72 \mathrm{~h}$; and $\operatorname{SID}_{3}$ was reduced at calving and increased up to $48 \mathrm{~h}$. The Ca levels were reduced until $24 \mathrm{~h}$ and increased up to $72 \mathrm{~h}$. Cows of third and fourth to sixth lactations presented lower values up to $24 \mathrm{~h}$. SCH was observed in almost half of the cows $443.3 \%$ to $55 \%$ ) until $48 \mathrm{~h}$. The maintenance of hypocalcemia for three or more consecutive days occurred in $53.3 \%$ of third and fourth to sixth lactations cows. Ingestion of a high chloride prepartum anionic diet led to hyperchloremic acidosis and this imbalance was reversed on the second postpartum day. The induced effects on electrolyte and acid-base balances were not able to prevent the occurrence of SCH in the first days of lactation.
\end{abstract}

INDEX TERMS: Hyperchloremic acidosis, hypocalcemia, transition period, serum electrolytes, ammonium chloride, calcium metabolism, dietary cation-anion difference, dairy cattle, prepartum diet, cattle.

${ }^{1}$ Received on May 30, 2020.

Accepted for publication on July 4, 2020.

${ }^{2} \mathrm{PhD}$ level student of the Graduate Program in Animal Health and Production Science, Centro de Ciências Agrárias, Universidade Estadual de Londrina (UEL), Campus Universitário, Rodovia Celso Garcia Cid PR-445 Km 380, Cx. Postal 10011, Londrina, PR 86057-970, Brazil.

${ }^{3}$ Setor de Veterinária e Produção Animal, Centro de Ciências Agrárias, Universidade Estadual do Norte do Paraná (UENP), Campus de Bandeirantes, Rodovia BR-369 Km 54, Vila Maria, Bandeirantes, PR 86360-000, Brazil.

\footnotetext{
${ }^{4}$ Departamento de Medicina Veterinária Preventiva, Centro de Ciências Agrárias, Universidade Estadual de Londrina (UEL), Campus Universitário, Rodovia Celso Garcia Cid PR-445 Km 380, Cx. Postal 10011, Londrina, PR 86057-970, Brazil.

${ }^{5}$ Departamento de Clínicas Veterinárias, Centro de Ciências Agrárias, Universidade Estadual de Londrina (UEL), Rodovia Celso Garcia Cid PR-445 Km 380, Cx. Postal 10011, Londrina, PR 86057-970, Brazil. *Corresponding author: janlisboa@uel.br
} 
RESUMO.- [Dieta aniônica pré-parto provoca acidose hiperclorêmica em vacas leiteiras de alta produção mas não evita a hipocalcemia subclínica.] Os objetivos do estudo foram avaliar os efeitos que a dieta aniônica pré-parto provoca sobre o equilíbrio eletrolítico e sobre a calcemia de vacas leiteiras de alta produção nos primeiros dias de lactação, e verificar o impacto sobre a frequência da hipocalcemia subclínica (HSC). Sessenta fêmeas hígidas HPB, com produção de $30 \mathrm{~kg}$ de leite/dia, manejadas em sistema intensivo (compost barn), foram distribuídas por grupos $(\mathrm{n}=15)$ de acordo com a ordem de lactação: primeira, segunda, terceira e quarta a sexta. Nas três semanas pré-parto receberam dieta com DCAD negativa $(-6 \mathrm{mEq} / 100 \mathrm{~g} \mathrm{MS})$ e teor de cloreto elevado. Após o parto receberam dieta com DCAD positiva (18mEq/100g MS). $\mathrm{O} \mathrm{pH}$ da urina foi mensurado antes do parto. As concentrações séricas de $\mathrm{Na}^{+}, \mathrm{Cl}^{-}, \mathrm{K}^{+}$e $\mathrm{Ca}$ total e a diferença de íons fortes $\left(\mathrm{SID}_{3}\right)$ foram determinadas em amostras colhidas ao parto (0h), 24, 48, 72 e $96 \mathrm{~h}$ após. As frequências de HSC foram determinadas considerando-se o valor crítico de $2,125 \mathrm{mmol} / \mathrm{L}(8,5 \mathrm{mg} / \mathrm{dL})$. ANOVA de medidas repetidas e teste de qui-quadrado foram empregados para as comparações. As vacas eliminavam urina ácida antes do parto. Os valores de $\mathrm{Na}^{+}, \mathrm{K}^{+}, \mathrm{Cl}^{-}$e $\mathrm{SID}_{3}$ não diferiram entre os grupos. $\mathrm{Na}^{+}$e $\mathrm{K}^{+}$não variaram entre os dias; $\mathrm{Cl}^{-}$era elevado ao parto e diminuiu até $72 \mathrm{~h} ; \mathrm{e} \mathrm{SID}_{3}$ era reduzida ao parto e aumentou até $48 \mathrm{~h}$. A calcemia era reduzida até $24 \mathrm{~h}$ e se elevou até $72 \mathrm{~h}$. Vacas de terceira e de quarta a sexta lactações apresentaram valores mais baixos até $24 \mathrm{~h}$. A HSC foi observada em quase metade das vacas $(43,3 \%$ a $55 \%)$ até $48 \mathrm{~h}$. A manutenção de hipocalcemia por três ou mais dias seguidos ocorreu em $53,3 \%$ das vacas de terceira e de quarta a sexta lactações. A ingestão de dieta aniônica pré-parto com alto teor de cloreto provocou acidose hiperclorêmica e este desequilíbrio se reverteu no segundo dia pós-parto. Os efeitos induzidos sobre os equilíbrios eletrolítico e ácido base não foram capazes de prevenir a ocorrência de HSC nos primeiros dias da lactação.

TERMOS DE INDEXAC̄̃̃O: Acidose hiperclorêmica, hipocalcemia, período de transição, eletrólitos séricos, cloreto de amônio, metabolismo do cálcio, diferença entre cátions e ânions na dieta, bovinos leiteiros, dieta pré-parto.

\section{INTRODUCTION}

High-yielding dairy cows, notably those with a higher number of lactations, have difficulty to maintain calcium (Ca) homeostasis in the early days of lactation because of the sudden and excessive loss of Ca by colostrum and the slow and insufficient response of the mechanisms responsible for maintaining calcemia in physiological levels (Oetzel 2013, Goff 2014). The resulting drop in blood Ca concentrations may be accentuated, causing hypocalcemic puerperal paresis (HPP), a disease also known as milk fever or clinical hypocalcemia, or it may be mild, characterizing subclinical hypocalcemia (SCH) (Lean et al. 2013). SCH is much more frequent than HPP, and can occur in around $50 \%$ of fresh multiparous cows (Reinhardt et al. 2011, Caixeta et al. 2015), and causes much greater economic loss because it is associated with the appearance of other diseases in the postpartum transition period (Kimura et al. 2006, DeGaris \& Lean 2009, Martinez et al. 2012).

Among the preventive measures for hypocalcemia, it should be emphasized the intake of anionic diet in the prepartum transition period, that is, in the last three weeks of pregnancy. This type of diet has a low value for the dietary cation-anion difference (DCAD), calculated by the equation DCAD $=(\mathrm{Na}+$ $\mathrm{K})-(\mathrm{Cl}+\mathrm{S})$. Unlike the conventional diet, in which cations predominate, the anionic diet has a higher concentration of anions and therefore, negative DCAD value (Constable 1999, 2014, DeGaris \& Lean 2009). Cows that eat a low DCAD diet develop metabolic acidosis which activates the mechanisms responsible for maintaining calcemia at a time when the metabolic demand for $\mathrm{Ca}$ is reduced. The previous activation of these mechanisms allows the cow to face the marked demand for $\mathrm{Ca}$ at the beginning of lactation in a reasonably balanced manner (Goff 2008, 2014).

The supply of diets with low DCAD at the end of pregnancy has been in use for four decades and is widespread, including in Brazilian dairy herds. Its effectiveness in reducing the incidence of HPP is proven (Charbonneau et al. 2006, Lean et al. 2013, Hassan et al. 2018). In the case of SCH, it is estimated that the intake of anionic diet can halve the incidence of this condition (Goff 2008, Oetzel 2013), however, there is a lack of scientific evidence to support this statement.

Metabolic acidosis resulting from low DCAD diets intake is well documented in dairy cows (Joyce et al. 1997, Gelfert et al. 2007, 2010, Zimpel et al. 2018). On the other hand, the influence of this type of diet on the variation of serum electrolytes before and after calving was presented in a single report (Grünberg et al. 2011). The study presented here aimed to evaluate the effects that the prepartum anionic diet has on the electrolyte balance and on the calcemia of high-producing, primiparous and multiparous dairy cows, during the first days of lactation, and to verify the impact on the frequency of SCH.

\section{MATERIALS AND METHODS}

The experimental protocol was approved by the Ethics Commission on the Use of Animals of the "Universidade Estadual de Londrina" (CEUA-UEL), registered as process number 13822.2017.94.

Animals and management. The present study was carried out on a dairy farm in the municipality of Toledo, Paraná, Brazil (latitude $24^{\circ} 42^{\prime} 49^{\prime \prime} \mathrm{S}$, longitude $53^{\circ} 44^{\prime} 35^{\prime \prime} \mathrm{W}$, and average altitude of $560 \mathrm{~m}$ ) from November 2017 to June 2018. Sixty apparently healthy Holstein cows, with an average milkyield of $30 \mathrm{~kg} /$ day, were included in the study. The cows belonged to a single farm, where they remained throughout the experimental period. The following groups (15 animals each) were composed according to the lactation order: first, second, third, and fourth to sixth lactations. The cows remained confined in facilities of compost barn type with efficient ventilation system and bed of shavings. At 60 days prepartum, the cows were dried and housed together forming a single batch. At 21 days prepartum, the cows were relocated to form a transition period group, remaining in this batch until calving. After calving, the calves were immediately separated and the cows were transferred to the lactation batch. Milking was performed three times a day (5:00 a.m., 1:30 p.m. and 9:00 p.m.) using a conventional mechanical milking system. In the newly calved cows, the first milking of the colostrum was performed at the next time of the milking routine, after milking all cows. Most of the cows included in this study calved at night and were milked at the morning milking time.

For inclusion in the study, cows should have a body condition score (BCS) between 3.0 and 3.5 and urinary $\mathrm{pH}$ with a range of 6.2 to 6.8 (Goff 2008,2014 ) in the period comprising the last two weeks 
before calving. Dystocic or assisted calvings and twin pregnancies were considered as exclusion criteria in the study.

Formulation and composition of diets. The diet was offered to the animals twice a day in the form of total mixed ration (TMR) and water was freely available. TMR offers took place at 8:00 a.m. and 3:00 p.m. The diet offered from 21 days before calving was formulated to achieve a negative DCAD and calculated for high-producing cows with an estimated weight of $650 \mathrm{~kg}$. The diet offered after calving was calculated considering the estimated weight of $580 \mathrm{~kg}$, and the expectation that the milk produced would contain concentrations of $3.7 \%$ and $3 \%$ for fat and proteins, respectively. A sample of each type of diet, anionic in the prepartum and cationic in lactation, was taken directly from the trough and subjected to bromatological and mineral analysis. The characteristics of the diets offered before and after calving are shown in Table 1.

DCAD was calculated using the equation DCAD (mEq/100g DM) $=\left[\left(\mathrm{Na}^{+}+\mathrm{K}^{+}\right)-\left(\mathrm{Cl}^{-}+\mathrm{S}^{2-}\right)\right]($ DeGaris \& Lean 2009). The conversion to a thousandth part of the Equivalent (mEq), was obtained from the atomic weight and valence of each cation or anion, using the formula DCAD (mEq/100g DM) $=\left[\left(\% \mathrm{Na}^{+} / 0.023+\% \mathrm{~K}^{+} / 0.039\right)-\right.$ (\% $\left.\left.\mathrm{Cl}^{-} / 0.0355+\% \mathrm{~S}^{2-} / 0.016\right)\right]$, and considering the percentage of cations and anions in DM.

Sample collection and laboratory analysis. The BCS and urine $\mathrm{pH}$ measurements were performed only once and on the same day, between seven and ten days before calving. The BCS was assessed using a scale from 1 to 5 (Edmonson et al. 1989). To minimize the subjectivity of the assessment, the BCS Cowdition app (Bayer Animal Health, Germany), available for smartphones, was used. Urine collection was performed by micturition induced by massage on the vulva and perineum and the $\mathrm{pH}$ was measured right after collection using an AK90 portable device (AKSO; São Leopoldo, RS).

Individual milk yield was measured on the 20th and 21st days of lactation, using milking controllers (Metatron 52; GEA Westfalia;

Table 1. Composition of diets offered in the prepartum and postpartum periods, and values recommended by the NRC (2001) for high-producing Holstein cows

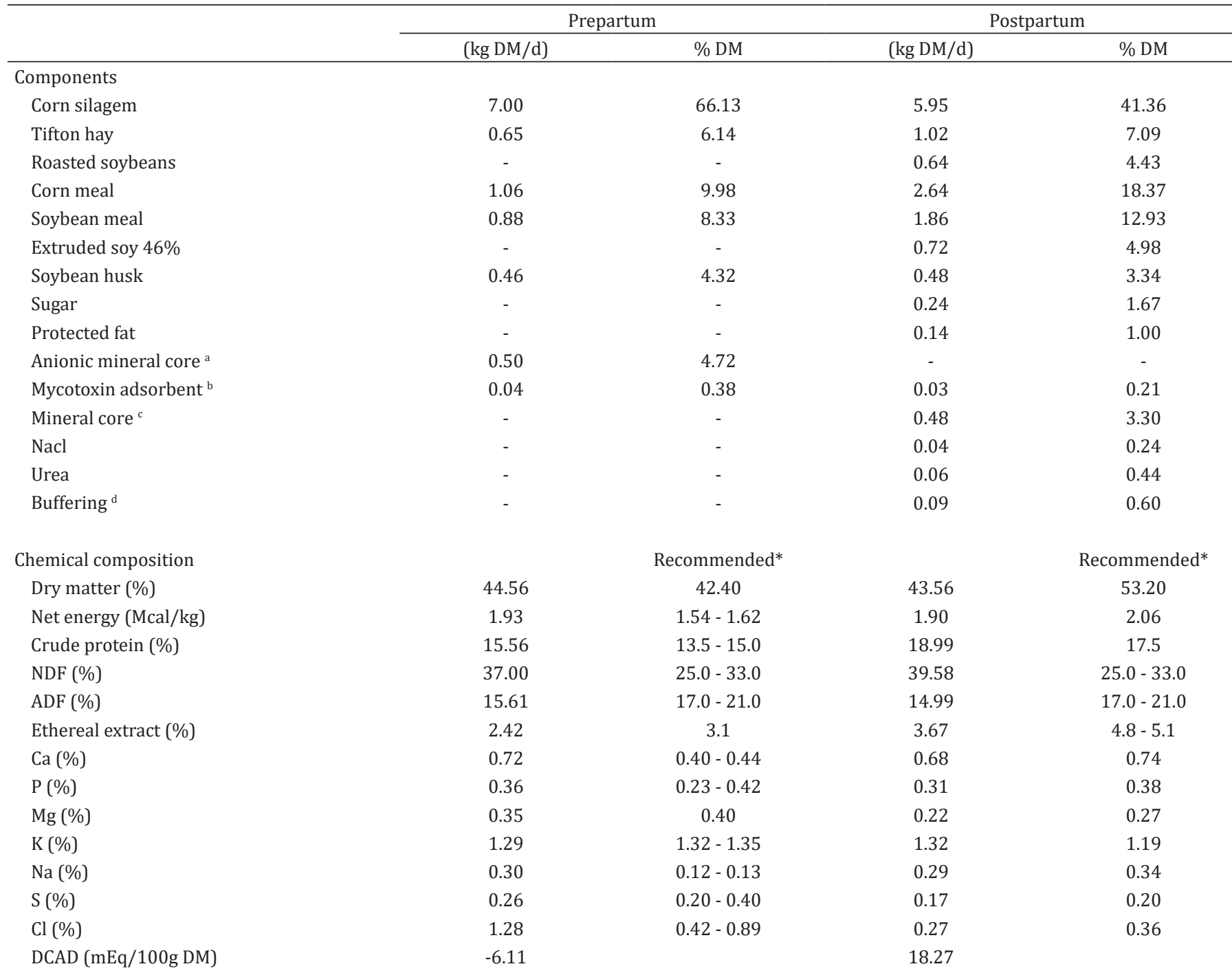

Consumption time: 21 days; DM = dry matter; a Núcleo Pré-parto Aniônico Salus ${ }^{\circledR}$ (Salus; Santo Antônio da Posse/SP), b Safetox Plus ${ }^{\circledR}$ (Safeeds; Cascavel/ PR), ' Núcleo Salus Lactação ${ }^{\circledR}$ (Salus; Santo Antônio da Posse/SP), ${ }^{d}$ Rumox ${ }^{\circledR}$ (Safeeds; Cascavel/PR); * Diets formulated according to the NRC (2001) for high-producing Holstein cows weighing approximately $650 \mathrm{~kg}$ before calving and 580kg at the beginning of lactation; NDF $=$ neutral detergent fiber, $\mathrm{ADF}=$ acid detergent fiber, DCAD = dietary cation-anion difference. 
Germany). The average value of the milk volumes produced in the two days was accepted as the yield value of each cow.

Venous blood samples were taken at five defined times: after calving (just after the first milking of colostrum and up to 5 hours after calving), 24, 48, 72 and 96 hours later. Blood samples were obtained by puncture of the coccygeal vein with $21 \mathrm{G}$ needles $(25 \mathrm{x}$ $0.8 \mathrm{~mm}$ ) from the vacuum collection system, using bottles without anticoagulant. Blood serum was obtained by centrifugation after clot retraction and preserved by freezing $\left(-20^{\circ} \mathrm{C}\right)$ until the time of the analyzes, performed up to 10 months after collection.

To determine serum total Ca concentrations, a colorimetric method and spectrophotometric reading (Dimension Xpand Plus ${ }^{\circledR}$; Siemens; São Paulo/SP) were used, using a specific commercial reagent (CA Flex ${ }^{\circledR}$ reagent cartridge; Siemens). The concentrations of sodium $\left(\mathrm{Na}^{+}\right)$, potassium $\left(\mathrm{K}^{+}\right)$and chlorides $\left(\mathrm{Cl}^{-}\right)$were measured using the ion selective electrode method (RAPIDPoint 500 System; Siemens Healthcare Diagnostics Inc.; USA). The strong ion difference $\left(\mathrm{SID}_{3}\right)$ was calculated using the following formula: $\mathrm{SID}_{3}=\left(\mathrm{Na}^{+}+\mathrm{K}^{+}\right)-(\mathrm{Cl})$ (Constable 2014).

Statistical analysis. One-way analysis of variance was used to compare milk production and urine $\mathrm{pH}$ between groups. For serum variables (total Ca, electrolytes and SID3), two-way repeated measures analysis of variance was used, testing the effect of time (days in milk - DIM), the effect of the lactation order and the interaction between these two factors. When the F statistic was significant, Tukey test was used for multiple comparisons.

The blood serum total Ca concentration of $2.125 \mathrm{mmol} / \mathrm{L}(8.5 \mathrm{mg} /$ $\mathrm{dL}$ ) was admitted as the critical value indicative of the equilibrium condition (Oetzel 2013, Farnia et al. 2018). The frequency distribution of cows with hypocalcemia was established on each of the first five DIM, and on each individual group, considering the maintenance of hypocalcemia for two or more consecutive days. The chi-square test was used to verify whether the occurrence of hypocalcemia was associated with DIM or lactation orders of cows.

Relationships between the studied variables were verified using Pearson's correlation test. For all statistical methods used, the probability of error of 5\% was admitted. All analyzes were performed in SigmaStat for Windows 3.1.

\section{RESULTS}

The studied cows showed milk yield of $30.99 \pm 7.32 \mathrm{~kg}$ at the end of the third week of lactation. According to the lactation order, the yield means were $28.99 \pm 6.48 \mathrm{~kg}, 32.99 \pm 7.67 \mathrm{~kg}$,
$31.48 \pm 6.06 \mathrm{~kg}$ and $30.51 \pm 8.92 \mathrm{~kg}$ in first, second, third and fourth to sixth lactation cows, respectively. There was no difference between groups $(\mathrm{P}=0.511)$.

The urine $\mathrm{pH}$, measured 7 to 10 days before calving, did not differ between groups $(\mathrm{P}=0.062)$ and showed an overall value of $6.65 \pm 0.30$. The values were $6.46 \pm 0.29$ in the first lactation cows, $6.71 \pm 0.25$ in the second lactation, $6.74 \pm 0.34$ in the third lactation and $6.70 \pm 0.24$ in the fourth to sixth lactations.

Unlike calcemia, the serum electrolyte concentrations in the first days of lactation were not influenced by the lactation order of the cows (Table 2). Considering the variations between DIM, on the other hand, the concentrations of $\mathrm{Na}^{+}$and $\mathrm{K}^{+}$ remained unchanged, while chloremia and $\mathrm{SID}_{3}$ showed an opposite behavior, with reduction and increase, respectively. The decrease of chloremia was completed within 72 hours and the $\mathrm{SID}_{3}$ elevation was complete within 48 hours postpartum.

The serum concentration of total Ca differed both between groups and between the first DIM, although there was no interaction between these factors (Table 2). The calcemia, lower at birth and at 24 hours, increased and maintained higher values after 72 hours. The influence of the groups was proven up to 24 hours postpartum and, after 48 hours, total Ca concentrations no longer differed between cows of different lactation orders (Fig.1). At calving, first and second

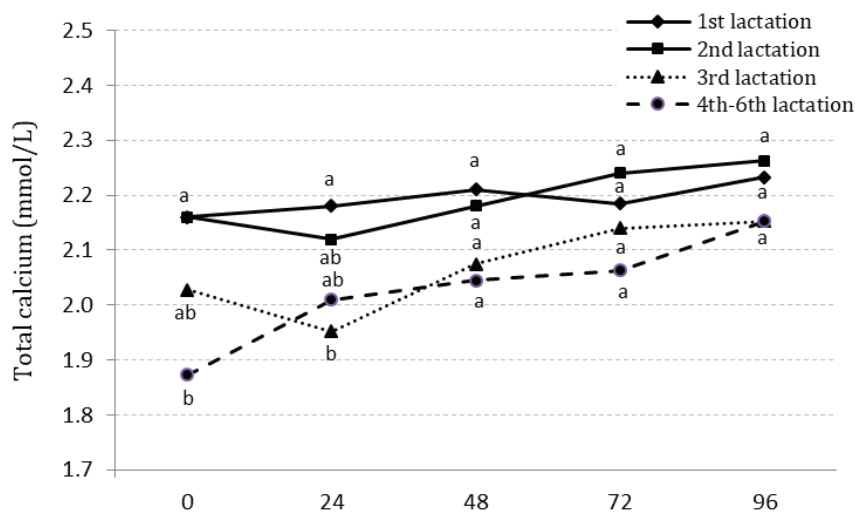

Fig.1. Variation of total calcium concentration in the blood serum, during the first 96 hours of lactation, of high-producing Holstein cows divided according to the lactation order $(\mathrm{n}=15$ each) and that received anionic diet before calving.

Table 2. Global mean values of sodium $\left(\mathrm{Na}^{+}\right)$, potassium $\left(\mathrm{K}^{+}\right)$, chloride $\left(\mathrm{Cl}^{-}\right)$and total calcium (Ca) concentrations and the strong ion difference ( $\mathrm{SID}_{3}$ ) in the blood serum of high-producing Holstein cows during the first five days in milk and who received anionic diet before calving. Effects of the lactation order and the day in milk, and interaction between the two factors

\begin{tabular}{|c|c|c|c|c|c|c|c|c|c|}
\hline & Calving & $24 \mathrm{~h}$ & $48 \mathrm{~h}$ & $72 \mathrm{~h}$ & $96 \mathrm{~h}$ & SEM & $\begin{array}{c}\text { LO } \\
P \text { value }\end{array}$ & $\begin{array}{c}\text { DIM } \\
P \text { value }\end{array}$ & $\begin{array}{c}\text { LO x DIM } \\
P \text { value }\end{array}$ \\
\hline $\begin{array}{l}\mathrm{Na}^{+} \\
(\mathrm{mmol} / \mathrm{L})\end{array}$ & 143.07 & 141.29 & 149.21 & 140.81 & 140.00 & 0.832 & 0.297 & 0.108 & 0.687 \\
\hline $\begin{array}{l}\mathrm{K}^{+} \\
(\mathrm{mmol} / \mathrm{L})\end{array}$ & 4.65 & 4.77 & 4.70 & 4.63 & 4.58 & 0.070 & 0.282 & 0.291 & 0.342 \\
\hline $\begin{array}{l}\mathrm{Cl}^{-} \\
(\mathrm{mmol} / \mathrm{L})\end{array}$ & $111.21^{\mathrm{a}}$ & $108.30^{\mathrm{b}}$ & $106.58^{b c}$ & $105.96^{c}$ & $105.33^{c}$ & 0.513 & 0.229 & $<0.001$ & 0.117 \\
\hline $\begin{array}{l}\mathrm{SID}_{3} \\
(\mathrm{mmol} / \mathrm{L})\end{array}$ & $36.51^{\mathrm{b}}$ & $37.76^{\mathrm{ab}}$ & $39.32^{\mathrm{a}}$ & $39.48^{a}$ & $39.25^{\mathrm{a}}$ & 0.693 & 0.275 & 0.005 & 0.532 \\
\hline $\mathrm{Ca}$ & $2.055^{b}$ & $2.065^{b}$ & $2.127^{\mathrm{ab}}$ & $2.155^{\mathrm{a}}$ & $2.200^{\mathrm{a}}$ & 0.028 & 0.007 & $<0.001$ & 0.396 \\
\hline
\end{tabular}

SEM = standard error of mean, LO = lactation orders: first lactation, second lactation, third lactation and fourth to sixth lactation (n=15 for each group), DIM = day in milk; ${ }^{a, b, c}$ different letters on the same line represent difference between days $(P<0.05)$. 
Table 3. Occurrence of subclinical hypocalcemia (total calcium concentration in blood serum $<2.125 \mathrm{mmol} / \mathrm{L}$ ) in high-producing Holstein cows in the first five days in milk and who received an anionic diet before calving

\begin{tabular}{lccccc}
\hline Lactation order & Calving & $24 \mathrm{~h}$ & $48 \mathrm{~h}$ & $72 \mathrm{~h}$ & $96 \mathrm{~h}$ \\
\hline 1st $(\mathrm{n}=15)$ & 2 & 4 & 3 & 6 & 2 \\
2nd (n=15) & 5 & 9 & 6 & 4 & 3 \\
3rd (n=15) & 10 & 12 & 6 & 5 & 4 \\
4th to 6th (n=15) & 12 & 8 & 11 & 5 & 5 \\
TOTAL (n=60) & 29 & 33 & 26 & 20 & 14 \\
& $(48.3 \%)$ & $(55 \%)$ & $(43.3 \%)$ & $(33.3 \%)$ & $(23.3 \%)$
\end{tabular}

lactation cows showed higher values than cows with four to six lactations, and 24 hours postpartum, first lactation cows had higher concentrations than third lactation cows.

Hypocalcemia was observed in practically half of the cows up to 48 hours after calving (Table 3 ) and the frequency of hypocalcemic cows decreased in the following days $(\mathrm{P}=0.004)$. The problem was less pronounced in cows with fewer lactations, especially in the first 48 hours in milk. Considering the maintenance of hypocalcemia for two or more consecutive days, this type of occurrence was observed in $58.3 \%(35 / 60)$ of the cows, with no difference between groups $(\mathrm{P}=0.257)$ : $40 \%(6 / 15)$ in heifers, and $53.3 \%(8 / 15), 73.3 \%(11 / 15)$ and $66.7 \%(10 / 15)$ in second, third and fourth to sixth lactation cows, respectively. When the hypocalcemia maintenance period was extended to three or more consecutive days, the occurrence dropped to $31.7 \%(19 / 60)$ of the cows and the difference between groups became marked $(\mathrm{P}=0.004)$; more frequently in the third and fourth to sixth lactation cows (53.3\%; 8/15 in both) and less frequently in primiparous $(6.7 \% ; 1 / 15)$ and in second lactation cows $(13.3 \% ; 2 / 15)$.

The concentrations of serum Ca at calving and at 24 hours of lactation did not correlate with those of $\mathrm{Na}^{+}$and $\mathrm{K}^{+}$, and showed a weak correlation with those of $\mathrm{Cl}^{-}(\mathrm{r}=-0.21 ; \mathrm{P}=0.021)$ and with $\operatorname{SID}_{3}(\mathrm{r}=0.27 ; \mathrm{P}=0.002)$.

\section{DISCUSSION}

The critical value of total serum Ca concentration below which $\mathrm{SCH}$ is defined is variable among the authors. The concentration of $2.0 \mathrm{mmol} / \mathrm{L}(8.0 \mathrm{mg} / \mathrm{dL})$ has been classically admitted for a long time (Goff 2008, DeGaris \& Lean 2009, Reinhardt et al. 2011) and is still accepted (Goff 2014, Caixeta et al. 2015). However, based on the study of Martinez et al. (2012), proving that serum Ca concentrations below $2.15 \mathrm{mmol} / \mathrm{L}(8.6 \mathrm{mg} /$ $\mathrm{dL}$ ) were related to decreased neutrophil activity, the value of $2.125 \mathrm{mmol} / \mathrm{L}(8.5 \mathrm{mg} / \mathrm{dL}$ ) came to be considered critical (Oetzel 2013, Farnia et al. 2018). Following the most current trend, SCH was admitted in the study presented here as a concentration below $2.125 \mathrm{mmol} / \mathrm{L}$. Values close to, but above these limits, could be assumed to be indicative of a physiological drop in calcemia near calving (Goff 2008, 2014, Oetzel 2013).

The percentages of hypocalcemic cows observed (Table 3) are consistent with those indicated in epidemiological surveys carried out in herds of Holstein cows (Reinhardt et al. 2011, Caixeta et al. 2015). This indicates that, with respect to the maintenance of calcemia in the first days of lactation, the studied cows behave similarly to North American high-producing cows. The difficulty in maintaining calcemia is more pronounced in cows with a higher number of lactations (Reinhardt et al. 2011), especially in the first 48 hours postpartum (Caixeta et al. 2015). As estimated by the results of a meta-analysis, the risk of hypocalcaemia is $9 \%$ higher with each subsequent lactation (Lean et al. 2013).

A result that must be highlighted is that SCH remained present for two or more consecutive days in a significant number of the studied cows. Half of the third and fourth to sixth lactation cows remained hypocalcemic for three or more days, unlike the younger cows. This discrepancy observed in relation to lactation orders clearly characterizes that the younger cows were able to recover their balance quickly, while the older cows exhibited more difficulty in reversing the metabolic imbalance. The increased risk of hypocalcemia with advancing age can be explained by different reasons: decreased number of receptors for calcitriol (active vitamin D) in enterocytes, decreased number of osteoblasts and active osteoclasts at bone remodeling sites, and probably a decrease in the number of receptors for parathyroid hormone (PTH) in renal cells (DeGaris \& Lean 2009, Goff 2014). The responses to positive stimuli for maintaining calcemia (PTH and calcitriol) are, therefore, slower and of lesser magnitude in cows with third or more lactations, highlighting the lower capacities of intestinal Ca absorption and bone Ca mobilization.

In the case of studied cows with three or more lactations, the greatest concern is not due to the magnitude of the hypocalcaemia itself, but rather to its prolonged duration. In average values, third lactation cows corrected calcemia 72 hours after calving and those from fourth to sixth lactations only 24 hours after this (Fig.1). The variation curve for serum Ca concentration in older cows is compatible with that obtained by Kimura et al. (2006) in Jersey cows, proven to be more susceptible than Holstein cows to developing postpartum hypocalcaemia (Goff 2014). The lowest concentrations of Ca were found at birth and 24 hours later, and the concentration of $2.125 \mathrm{mmol} / \mathrm{L}$ was only achieved with 96 hours of lactation (Kimura et al. 2006). The persistence of SCH during the first four days of lactation may increase the risk of older cows developing other related diseases in the postpartum transition period (Goff 2008, 2014, DeGaris \& Lean 2009, Oetzel 2013), in addition to having impaired reproductive function (Caixeta et al. 2017), which causes economic loss. The occurrence of diseases was not evaluated in the studied cows, but milk yield did not differ between groups at the end of the third week of lactation.

Even if we considered the critical value of $2.0 \mathrm{mmol} / \mathrm{L}$ for the concentration of $\mathrm{Ca}$ in blood serum, the prevalence of SCH would remain high at the beginning of the observation period: $35 \%$ of cows at calving, $40 \%$ at 24 hours, $20 \%$ at 48 hours, $16.7 \%$ at 72 hours and $13.3 \%$ at 96 hours postpartum. Half of the third $(8 / 15,53.3 \%)$ and fourth and sixth lactation cows $(8 / 15,53.3 \%)$ maintained hypocalcemia for two or more consecutive days. SCH must therefore be understood as a relevant problem in the studied herd, and it is clear that the intake of anionic diet in the prepartum transition period did not contribute to preventing this imbalance.

The diet eaten in the last three weeks of pregnancy has the characteristics of an anionic diet. The DCAD is negative $(-6.11 \mathrm{mEq} / 100 \mathrm{~g} \mathrm{DM})$ because the chloride concentration is very high (Table 1 ) and the sum of anions $\left(\mathrm{Cl}^{-}\right.$and $\mathrm{S}^{2}$ ) exceeds the sum of cations $\left(\mathrm{Na}^{+}\right.$and $\left.\mathrm{K}^{+}\right)$. The anionic mineral core 
used in the preparation of TMR contained $\mathrm{NaCl}$ and $\mathrm{NH}_{4} \mathrm{Cl}$ as sources of chloride and $\mathrm{MgSO}_{4}$ as the main source of sulfur. Due to the markedly high chloride content in the diet, it is correct to say, therefore, that $\mathrm{NH}_{4} \mathrm{Cl}$ was the main anionic salt ingested by cows. After calving, the cows began to receive the typically cationic lactation diet (DCAD of $18.27 \mathrm{mEq} / 100 \mathrm{~g}$ $\mathrm{DM}$ ), with reduced chloride content due to the removal of $\mathrm{NH}_{4} \mathrm{Cl}$ from the composition.

The effects of the ingestion of anionic diet before calving and the sudden change to the cationic lactation diet on the electrolyte balance of the studied cows are clearly demonstrated in Table 2. While the concentrations of $\mathrm{Na}^{+}$and $\mathrm{K}^{+}$remained unchanged, chloremia, elevated at calving, decreased rapidly and plasma $\operatorname{SID}_{3}$, decreased at calving, increased. This proves that the anionic diet caused hyperchloremia in the cows and that the electrolyte imbalance was promptly reversed when they started to receive the lactation diet.

Although the blood gas analysis was not performed, it is possible to state that the studied cows developed the state of metabolic acidosis based on the fact that they eliminate acidic urine (Constable et al. 2009). According to the strong ion theory, hyperchloremia, determining the decrease of $\mathrm{SID}_{3}$ in plasma, is the primary imbalance caused by the anionic diet and metabolic acidosis is installed as a mandatory consequence (Constable 1999, 2014). It can be concluded, therefore, that the ingestion of the anionic supplement rich in $\mathrm{NH}_{4} \mathrm{Cl}$ caused hyperchloremic acidosis in cows in late gestation.

These same types of electrolyte and acid-base imbalances have been proven in goats (Singh et al. 2007) and in sheep (Ferreira et al. 2014) that ingested $\mathrm{NH}_{4} \mathrm{Cl}$ for the purpose of acidifying urine to prevent urolithiasis. The excess of ingested chloride causes an increase in the urinary fractional excretion of chlorides (Stratton-Phelps \& House 2004, Mavangira et al. 2010, Ferreira et al. 2018) and this explains the reduction in the urine $\mathrm{pH}$, since the higher concentration of chlorides reduces urinary $\mathrm{SID}_{3}$ (Constable et al. 2009). Other studies using sheep have shown that hyperchloremic acidosis also occurs with the ingestion of other types of anionic salts based on chlorides, such as $\mathrm{CaCl}_{2}$ (Espino et al. 2003), $\mathrm{HCl}$ (Las et al. 2007) and $\mathrm{MgCl}_{2}$ (Wilkens et al. 2016).

Variations in serum electrolytes in newly calved cows that received a chloride-rich anion diet in the prepartum transition period were previously presented in a single record (Grünberg et al. 2011). The results obtained were similar to those of the study presented here, however, unlike the studied cows, serum $\mathrm{Na}^{+}$concentrations were reduced after calving. Hyperchloremic metabolic acidosis has also been proven, as well as urine acidification with increased $\mathrm{Cl}^{-}$excretion, and these imbalances were quickly reversed after calving by switching to a lactation diet containing low chloride content. More recently, the results obtained by Zimpel et al. (2018) in cows at the end of gestation reinforce the evidence that hyperchloremic acidosis is, in fact, the imbalance caused by the anionic diet.

The acidogenic effect of the anionic diet is expected and desirable so that it can play its role in helping to maintain Ca homeostasis in high-producing dairy cows that begin lactation (DeGaris \& Lean 2009, Goff 2014). Among the suggested mechanisms, currently stands out the evidence that metabolic acidosis induces hypercalciuria by decreasing tubular calcium reabsorption when urine is acidic (Gelfert et al. 2007, 2010, Grünberg et al. 2011, Farnia et al 2018, Lopera et al. 2018, Zimpel et al. 2018). The continuous loss of calcium through the urine in the last weeks of pregnancy activates the mechanisms involved in the maintenance of calcemia, and mediated by PTH and calcitriol. After calving, with the suspension of anionic diet intake, the metabolic acidosis is quickly reversed (Joyce et al. 1997), the urine returns to alkaline (Grünberg et al. 2011) and the elimination of Ca by the urine ceases promptly (Farnia et al. 2018), contributing to increase blood Ca concentration. The previous activation of the mechanisms of bone Ca mobilization, calcitriol synthesis and active intestinal $\mathrm{Ca}$ absorption, enables the cow kept on anionic diet in the prepartum transition period to respond efficiently to the great challenge imposed by the sudden loss of Ca for colostrum (Goff 2008, 2014).

Ingestion of anionic diet at the end of pregnancy is proven to be effective in preventing the occurrence of HPP (Joyce et al. 1997, Charbonneau et al. 2006, DeGaris \& Lean 2009, Lean et al. 2013, Hassan et al. 2018), also called clinical hypocalcemia, certainly because it prevents the fall of calcemia from being very accentuated at the beginning of lactation. In fact, during the study period, the frequency of HPP cases was very low in the herd $(9 / 591 ; 1.5 \%)$. Reducing DCAD in the prepartum transition period has other advantages for multiparous cows in the beginning of lactation, such as increased dry matter intake and milk yield, and reduced risk of developing diseases, notably retained placenta and metritis (Santos et al. 2019). It is, therefore, a preventive management measure that is fully justified in high-producing dairy cows.

However, its effectiveness in preventing the occurrence of SCH is doubtful (Joyce et al. 1997, Farnia et al. 2018, Lopera et al. 2018) and the obtained results reinforce this. It is consistent to assume that the improvement produced in Ca metabolism is accompanied by an increase in blood Ca concentration sufficient to prevent the occurrence of HPP, but not always sufficient to prevent the occurrence of $\mathrm{SCH}$. The ability of the anionic diet to decrease the frequency and duration of SCH in dairy herds is a relevant issue that needs to be further investigated.

\section{CONCLUSION}

The ingestion of a prepartum anionic diet with a high content of ammonium chloride causes hyperchloremic acidosis, an imbalance that is reversed on the second postpartum day. These effects on electrolyte and acid-base balances did not prevent the occurrence of subclinical hypocalcemia in highyielding cows in the early days in milk.

Acknowledgements.- This work was supported by the CNPq/INCT-Leite under Grant (Number 465725/2014-7) and by PROEX/CAPES 1959/2015. Júlio A.N. Lisbôa is recipient of the "Conselho Nacional de Desenvolvimento Científico e Tecnológico" (CNPq) fellowship.

Conflict of interest statement.- We have no conflict of interest to declare.

\section{REFERENCES}

Caixeta L.S., Ospina P.A., Capel M.B. \& Nydam D.V. 2015. The association of subclinical hypocalcemia, negative energy balance and disease with bodyweight change during the first 30 days post-partum in dairy cows milked with automatic milking systems. Vet. J. 204(2):150-156. <http:// dx.doi.org/10.1016/j.tvjl.2015.01.021> <PMid:25819756> 
Caixeta L.S., Ospina P.A., Capel M.B. \& Nydam D.V. 2017. Association between suclinical hypocalcemia in the first 3 days of lactation and reproductive performance of dairy cows. Theriogenology 94:1-7. <http://dx.doi. org/10.1016/j.theriogenology.2017.01.039><PMid:28407850>

Charbonneau E., Pellerin D. \& Oetzel G.R. 2006. Impact of lowering dietary cation-anion difference in nonlactating dairy cows: a meta-analysis. J. Dairy Sci. 89(2):537-548. <http://dx.doi.org/10.3168/jds.S0022-0302(06)72116-6> <PMid:16428622>

Constable P.D. 1999. Clinical assessment of acid-base status: strong ion difference theory. Vet. Clin. N. Am., Food Anim. Pract. 15(3):447-471. <http://dx.doi.org/10.1016/S0749-0720(15)30158-4><PMid:10573806>

Constable P.D. 2014. Acid-base assessment: when and how to apply the Henderson-Hasslbalch equation and strong ion difference theory. Vet. Clin. N. Am., Food Anim. Pract. 30(2):295-316. <http://dx.doi.org/10.1016/j. cvfa.2014.03.001><PMid:24980723>

Constable P.D., Gelfert C.C., Fürll M., Staufenbiel R. \& Stämpfli H.R. 2009. Application of strong ion difference theory to urine and the relationship between urine $\mathrm{pH}$ and net acid excretion in cattle. Am. J. Vet. Res. 70(7):915925. <http://dx.doi.org/10.2460/ajvr.70.7.915><PMid:19566478>

DeGaris P.J. \& Lean I.J. 2009. Milk fever in dairy cows: a review of pathophysiology and control principles. Vet. J. 176(1):58-69. <http://dx.doi.org/10.1016/j. tvjl.2007.12.029><PMid:18329301>

Edmonson A.J., Lean I.J., Weaver L.D., Farver T. \& Webster G. 1989. A body condition scoring chart for Holstein dairy cows. J. Dairy Sci. 72(1):68-78. <http://dx.doi.org/10.3168/jds.S0022-0302(89)79081-0>

Espino L., Guerrero F., Suarez M.L., Santamarina G., Goicoa A. \& Fidalgo L.E. 2003. Long-term effects of dietary anion-cation balance on acid-base status and bone morphology in reproducing ewes. J. Vet. Med. A 50(10):488-495. <http://dx.doi.org/10.1111/j.1439-0442.2004.00590.x><PMid:15157015>

Farnia S.A., Rasooli A., Nouri M., Shahryari A., Bakhtiary M.K. \& Constable P.D. 2018. Effect of postparturient oral calcium administration on serum total calcium concentration in Holstein cows fed diets of different dietary cation-anion difference in late gestation. Res. Vet. Sci. 117:118-124. <http:// dx.doi.org/10.1016/j.rvsc.2017.11.017><PMid:29253737>

Ferreira D.O.L., Santarosa B.P., Sacco S.R., Dias A., Amorim R.M., Chiacchio S.B., Lisbôa J.A.N. \& Gonçalves R.C. 2014. Efeito da suplementação de cloreto de amônio sobre os equilíbrios eletrolítico e ácido-básico e o pH urinário de ovinos confinados. Pesq. Vet. Bras. 34(8):797-804. <http:// dx.doi.org/10.1590/S0100-736X2014000800016>

Ferreira D.O.L., Santarosa B.P., Sacco S.R., Pereira P.F.V., Camilo S.L.O., Lisbôa J.A.N. \& Gonçalves R.C. 2018. Excreção fracionada urinária de sódio, potássio e cloreto em cordeiros suplementados com cloreto de amônio para prevenção de urolitíase. Pesq. Vet. Bras. 38(5):870-874. <http://dx.doi.org/10.1590/1678-5150-pvb-5396>

Gelfert C.C., Loeffler L.M., Frömer S., Engel M., Hartmann H., Männer K., Baumgartner W. \& Staufenbiel R. 2007. The impact of dietary cation anion difference (DCAD) on the acid-base balance and calcium metabolism of non-lactating, non-pregnant dairy cows fed equal amounts of different anionic salts. J. Dairy Res. 74(3):311-322. <http://dx.doi.org/10.1017/ S0022029907002439><PMid:17451620>

Gelfert C.C., Loeffler L.M., Frömer S., Engel M., Männer K. \& Staufenbiel R. 2010. Comparison of the impact os different anionic salts on the acid-base status and calcium metabolism in non-lactating, non-pregnant dairy cows. Vet. J. 185(3):305-309. <http://dx.doi.org/10.1016/j.tvjl.2009.06.013> <PMid:19709906>

Goff J.P. 2008. The monitoring, prevention, and treatment of milk fever and subclinical hypocalcemia in dairy cows. Vet. J. 176(1):50-57. <http://dx.doi.org/10.1016/j.tvjl.2007.12.020> <PMid:18342555>

Goff J.P. 2014. Calcium and magnesium disorders. Vet. Clin. N. Am., Food Anim. Pract. 30(2):359-381. <http://dx.doi.org/10.1016/j.cvfa.2014.04.003> $<$ PMid:24980727>

Grünberg W., Donkin S.S. \& Constable P.D. 2011. Periparturient effects of feeding a low dietary cation-anion difference diet on acid-base, calcium, and phosphorus homeostasis and on intravenous glucose tolerance test in high-producing dairy cows. J. Dairy Sci. 94(2):727-745. <http://dx.doi. org/10.3168/jds.2010-3230><PMid:21257041>

Hassan E.B., Nouri M., Vogrin S. \& Pyman M. 2018. Can neutral dietary cationanion difference (DCAD) decrease occurrence of clinical periparturient hypocalcaemia in dairy cattle? Austr. Vet. J. 96(7):269-273. <http://dx.doi. org/10.1111/avj.12712><PMid:29944750>

Joyce P.W., Sanchez W.K. \& Goff J.P. 1997. Effect of anionic salts in prepartum diets based on alfalfa. J. Dairy Sci. 80(11):2866-2875. <http://dx.doi. org/10.3168/jds.S0022-0302(97)76251-9><PMid:9406079>

Kimura K., Reinhardt T.A. \& Goff J.P. 2006. Parturition and hypocalcemia blunts calcium signals in immune cells of dairy cattle. J. Dairy Sci. 89(7):2588-2595. <http://dx.doi.org/10.3168/jds.S0022-0302(06)72335-9><PMid:16772578>

Las J.E., Odongo N.E., Lindinger M.I., AlZahal O., Shoveller A.K., Matthews J.C. \& McBride B.W. 2007. Effects of dietary strong acid anion challenge on regulation of acid-base balance in sheep. J. Anim. Sci. 85(9):2222-2229. <http://dx.doi.org/10.2527/jas.2007-0036><PMid:17504956>

Lean I.J., Van Saun R. \& DeGaris P.J. 2013. Mineral and antioxidant management of transition dairy cows. Vet. Clin. N. Am., Food Anim. Pract. 29(2):367386. <http://dx.doi.org/10.1016/j.cvfa.2013.03.004><PMid:23809896>

Lopera C., Zimpel R., Vieira-Neto A., Lopes F.R., Ortiz W., Poindexter M., Faria B.N., Gambarini M.L., Block E., Nelson C.D. \& Santos J.E.P. 2018. Effects of level of dietary cation-anion difference and duration of prepartum feeding on performance and metabolismo of dairy cows. J. Dairy Sci. 101(9):79077929. <http://dx.doi.org/10.3186/jds.2018-14580><PMid:29885896>

Martinez N., Risco C.A., Lima F.S., Bisinptto R.S., Greco L.F., Ribeiro E.S., Maunsell F., Galvao K. \& Santos J.E. 2012. Evaluation of peripartal calcium status, energetic profile, and neutrophil function in dairy cows at low or high risk of developing uterine disease. J. Dairy Sci. 95(12):7158-7172. <http://dx.doi.org/10.3168/jds.2012-5812> <PMid:23021755>

Mavangira V., Cornish J.M. \& Angelos J.A. 2010. Effect of ammonium chloride supplementation on urine $\mathrm{pH}$ and urinary fractional excretion of electrolytes in goats. J. Am. Vet. Med. Assoc. 237(11):1299-1304. <http://dx.doi. org/10.2460/javma.237.11.1299><PMid:21118016>

Oetzel G.R. 2013. Oral calcium supplementation in peripartum dairy cows. Vet. Clin. N. Am., Food Anim. Pract. 29(2):447-455. <http://dx.doi. org/10.1016/j.cvfa.2013.03.006><PMid:23809900>

Reinhardt T.A., Lippolis J.D., McCluskey B.J., Goff J.P. \& Horst R.L. 2011. Prevalence of subclinical hypocalcemia in dairy herds. Vet. J. 188(1):122124. <http://dx.doi.org/10.1016/j.tvjl.2010.03.025><PMid:20434377>

Santos J.E.P., Lean I.J., Golder H. \& Block E. 2019. Meta-analysis of the effects of prepartum dietary cation-anion difference on performance and health of dairy cows. J. Dairy Sci. 102(3):2134-2154. <http://dx.doi.org/10.3168/ jds.2018-14628> <PMid:30612801>

Singh T., Amarpal A., Kinjavdekar P., Aithal H.P., Pawde A.M. \& Pratap K. 2007. Blood acid-base and electrolyte changes following oral administration of ammonium chloride in goats suffering from obstructive urolithiasis. Indian J. Anim. Sci. 77(8):745-748.

Stratton-Phelps M. \& House J.K. 2004. Effect of a commercial anion dietary supplement on acid-base balance, urine volume, and urinary ion excretion in male goats fed oat or grass hay diets. Am. J. Vet. Res. 65(10):1391-1397. <http://dx.doi.org/10.2460/ajvr.2004.65.1391><PMid:15524326>

Wilkens M.R., Praechter C., Breves G. \& Schröder B. 2016. Stimulating effects of a diet negative in dietary cation-anion difference on calcium absorption from the rumen in sheep. J. Anim. Physiol. Anim. Nutr. 100(1):156-166. <http://dx.doi.org/10.1111/jpn.12296><PMid:25643625>

Zimpel R., Poindexter M.B., Vieira-Neto A., Block E., Nelson C.D., Staples C.R., Thatcher W.W. \& Santos J.E.P. 2018. Effect of dietary cation-anion difference on acid-base status and dry matter intake in pregnant cows. J. Dairy Sci. 101(9):8461-8475. <http://dx.doi.org/10.3168/jds.201814748><PMid:29970257> 